\title{
“INFORMING OF THE CHILD'S UNDERSTANDING, INFLUENCING HIS HEART, AND DIRECTING ITS PRACTICE": JONATHAN EDWARDS ON EDUCATION
}

\begin{abstract}
This article examines the role of education in Jonathan Edwards' life and legacy, both the education he received in early eighteenth-century New England and his activities as a teacher, among the other vocations he followed. In particular, the methods and principles he employed as a teacher, both of English and Indian children and young people, are distinctive. Next, the essay turns to some selected figures within the Edwardsean tradition to show pedagogical changes and continuities.
\end{abstract}

In one of his "Miscellanies," Jonathan Edwards, pastor of Northampton, Massachusetts, described a physics lesson he gave to a local thirteen-yearold boy, in which he asserted "that a piece of any matter of two inches square" was "eight times so big as one of but one inch square, or that it might be cut into eight pieces, all of them as big as that of but an inch square." The boy suspected that his pastor was playing a joke on him, but, Edwards wrote, "I took considerable pains to convince him that I was in earnest," whereat the lad "cried out of the impossibility and absurdity of it." To prove his point, Edwards led the boy to the woodshed, picked up a saw and cut "two cubes, one an inch and another two inches square, and let him examine the measures and see that the measures were exact, and that there was no deceit." He then "cut the two-inch cube into eight equal parts" and handed them to the boy," who "took the parts one by one and compared them with the one inch cube, and spent some time in counting and comparing." With the proof in his hands, the boy was still "astonished[,] as though there were some witchcraft in the case."

Kenneth P. Minkema, Yale University. Research associate: Dpt. Church history and ecclesiology, University of the Free State, South Africa. E-mail: Kenneth. Minkema@yale.com.

Acta Theologica

2011 31(2): $159-189$

doi: http://dx.doi.org/10.4314/actat.v31i2.8

ISSN 1015-8758

(C) UV/UFS

<http://www.uovs.ac.za/ActaTheologica> 
He could not understand it, Edwards explained, "for he did not yet at all see the reason of it" - that is, no one had taught him the larger concepts of volume and mass behind the seeming paradox (Chamberlain 2000: "Miscellanies" no. $652,192)$.

This story, meant to convey that there are even more difficult mysteries in religion than in this mathematics puzzle, gives a rare glimpse into Edwards teaching by experience, observation, and demonstration, much the same spirit of investigation that informs his youthful compositions such as "The Spider Letter" (Anderson 1980:163-70). The role of education in Jonathan Edwards' life and legacy is something that scholars and devotées often mention but have not discussed in anything like a concerted manner. In order to ascertain Edwards' influence on pedagogy among the community of New Divinity adherents, we must first look at Edwards himself, his educational formation, and the methods he employed as a teacher himself. Next, we shall turn to some selected figures within the Edwardsean tradition to show pedagogical changes and continuities.

\section{TIMOTHY EDWARDS' PREPARATORY SCHOOL}

In the months before he was settled as the first minister of East Windsor, Connecticut, in 1694, Timothy Edwards taught a Latin grammar school that prepared boys for entrance into college. New England laws required the establishment of an elementary school in towns of fifty or more families, and of a grammar school in those of at least one hundred families. Although newly settled, East Windsor met at least the first criteria (Stelting 1998:128-49).

Timothy Edwards would have been a demanding taskmaster. From the minister under whom he had rusticated, Peletiah Glover of Springfield, Massachusetts, he had acquired an appreciation for classical arts and a keen sense of self-discipline. Timothy became known as a serious Hebrew scholar who was also familiar with the latest learning, and who even wrote the occasional poem. Ever in search of supplementary income for his large and growing family, Timothy set up a preparatory school for local boys in the southwest room of the first floor of their house, lined with benches along the walls. Here the boys, along with all of the Edwards children - ten daughters and one son - were taught the catechism, composition, grammar, logic, and classical languages. The family library had its share of English, Latin and Greek grammars, textbooks, and other pedagogical tools. ${ }^{1}$

1 See an inventory of Timothy Edwards' library in Thuesen 2008:363-415. Hereafter, volumes to be found in The Works of Jonathan Edwards Online at the Jonathan Edwards Center's website, edwards.yale.edu, will be referred to as WJEO plus the volume number. 
Female education and female educators were distinguishing marks of this progressive, evangelical family. Timothy's wife, Esther Stoddard Edwards, assisted in the lessons. She was known to be liberally educated and possessed of more "native understanding" than her husband, whose knowledge was more esoteric; after Timothy died, she held theological classes for local women. Their daughters consulted Bible commentaries in Latin, read Addison and Steele, and, in contrast to their brother, wielded rapier-like wits. When they came of age, they took their turns as tutors; when Timothy was absent, for example, the older daughters put young Jonathan and the local boys through their paces. The older children were expected to listen to the younger recite their "tongues" every day. ${ }^{2}$

As was typical of the New England grammar school tradition, Timothy stressed rote learning and perfect recall. When he was gone from home as an army chaplain in 1711, he wrote to Esther:

I desire thee to take care that Jonathan don't lose what he hath learned, but that as he hath got the accidence, and above two sides of propria quae moribus by heart, so that he keep what he hath got, I would therefore have him say pretty often to the girls. I would also have the girls keep what they have learnt of the grammar, and get by heart as far as Jonathan hath learnt. ${ }^{3}$

Tradition has it that he gained so good a reputation for training boys for college that, upon presenting themselves for matriculation, they were not required to submit to the usual examination, with the explanation that anyone coming from Timothy Edwards was sure to be proficient. Edwards matriculated at the fledgling Connecticut Collegiate School in 1716, and attended the Weathersfield branch, under the tutelage of Elisha Williams. It wasn't until 1719 , after some false starts, that the students were assembled from various locations and the institution named Yale College, after its benefactor, Elihu Yale. The college curriculum at the time was based on the medieval formula of the trivium (grammar, logic, and rhetoric) and quadrivium (algebra, geometry, astronomy, and music). Students would have focused on languages in their early years, and in logic, metaphysics and mathematics in their later years. There was also a great deal of reciting: daily from English to Greek, from Hebrew to Greek, from Latin to English; on Fridays from Wollebius; on Saturdays from William Ames' Medulla and the Assembly's Shorter Catechism;

2 On the Edwards' preparatory school in their East Windsor, Connecticut, home, see Stoughton 1883:76-80; Winslow 1941:41-40; Minkema 1992:35-56.

3 Timothy Edwards to Esther Stoddard Edwards, 7 August 1711, Edwards Manuscripts, Franklin Trask Library, Andover Newton Theological School (hereafter ANTS), f. 1700-1719A, \#11; transcription in WJEO 32, Letter C6. 
and on Sundays from Ames again, this time Cases of Conscience (Morris 2005:64-65).

His home and collegiate education provided the foundation on which Jonathan Edwards built his own instructional theories and method, to which we now turn. The following discussion of Edwards' writings about teaching is arranged not chronologically but by life course phase. Thus, we will first consider his theory and practice for children, then for young people in pastoral and collegiate settings, followed by his education of ministerial candidates in his own home.

\section{TEACHING CHILDREN}

As a father of eleven and as pastor of the church of Northampton, Massachusetts, which had scores of children, one of Edwards' responsibilities was to start inculcating habits of study, character, and piety early in his youngest charges, "children" being those under fifteen years of age. His approach to bringing up his own children perhaps is the best indicator of the model he would have tried to set for other parents:

He took opportunities to treat with [his children] in his study, singly and particularly, about their own soul's concerns; and to have give them warning, exhortation, and direction, as he saw occasion. He took much pains to instruct them in the principles of religion; in which he made use of the Assembly's Catechism: not merely by taking care that they learned it by heart, but by leading them into an understanding of the doctrines therein taught, by asking them questions on each answer, and explaining it to them. His usual time to attend this was on the evening before the Sabbath. One thing to notice is that, while we see that he here retained some emphasis on memorization, he also posed questions back to his children, and expounded on them. As we shall see, he would expand on this strategy (Hopkins 1765:47).

Sermons were also an important pedagogical tool, and in them he addressed parents and children. To encourage parents, he preached on the importance of educating their children, as in a sermon from February 1745, in which he taught that "The religious education of children is one of the principle means of grace that God has appointed in his church." 4 Parents had the duty to bring up their children in "nurture and admonition," within the family and within the church, forming their characters early so that they would be under "best advantage" later in life for being of service and subjects of conversion.

4 See Edwards, MS sermon no. 770, on Ps. 78:5-7 (WJEO 63); see also no. 891, on Eph. 6:4, "1. That parents should bring up their children in Christianity ..." Feb. 1748 (WJEO 66). 
As Edwards explained in a different sermon, training up a child in the way he or she should go was "a principal means of grace" upon which "the continuation of the church" was dependent. "The easiest way of reforming a people in the world," he went on to say, "is by education."

As he did with other age groups, Edwards composed sermons tailored for children. One particularly graphic learning experience - reminiscent of the way in which Edwards showed the thirteen-year-old boy about the divisibility of the two-inch cube by demonstration - occurred in December 1742. John Lyman's house had burned, in which, tragically, two of his children had died. After preaching a sermon about God's "awful rebukes of providence," Edwards gathered the children of the church together and walked them over to view the charred remains of the structure. ${ }^{6}$ This strikes modern readers as cruel, but Edwards and his contemporaries would have felt such a measure justified if it meant that a youngster's soul would be saved.

Finally, we cannot leave this topic without mentioning four-year-old Phebe Bartlett, whom Edwards made famous in A Faithful Narrative. Her zeal for "closet" devotions, her concern over the souls of her siblings, and her affection for her pastor - as Edwards described them, anyway - made her a paragon of childish piety (Goen 1972:199-205).

\section{LETTER TO WILLIAM PEPPERRELL}

Next, we must go nearly to the end of Edwards' career, when he had taken up the missionary post at Stockbridge, where he dealt with a very different set of children. In November 1751, he wrote a key letter to Sir William Pepperrell, the hero of the Louisburg campaign of 1745 and a supporter of the Indian mission. Edwards had visited Sir William and his wife in the spring of the year at their home in Kittery, Maine, when the two had discussed the prospects for the mission. In the meantime, Edwards had received a letter from the

$5 \quad$ MS, [Sermon notes on educating children,] n.d., ANTS.

6 No. 691, on Mic. 6:9, "I. God's voice sometimes cries to a city or town in the awful rebukes of his providence. II. The men of wisdom shall see God's name," Dec 9, 1742, "On occasion of burning of John Lyman's house and children, which was on Wed. night, Dec. 8, 1742" (WJEO 60). For other sermons to children, see no. 563, on Matt. 10:37(a), "Children ought to love the Lord Jesus Christ above all things in this world," Aug. 1740, "To the children," published as Children Ought to Love the Lord Jesus Christ Above All, in Stout and Hatch 2003:167-80; no. 592, on II Kgs. 2:23-24, "God is very angry at the sins of children," Feb. 1741, "To the children at a private meeting," published as God Is Very Angry at the Sins of Children, in Nichols 2001:425-35; and no. 622, on Ps. 34:11, "Therefore now I would improve this scripture to call upon you children now to forsake your sins and seek the fear of God," July 1741, "Private meeting of children" (WJEO 58). 
colonial secretary, Andrew Oliver, about "a proper plan of a school for Indian girls in this place." The resulting letter is Edwards' most complete statement of his philosophy of education, which he sought to implement in his time at Stockbridge with teachers Timothy Woodbridge and Gideon Hawley, and with funds from English philanthropists such as Sir Peter Warren and Rev. Isaac Hollis (Davies 2006).

As the plans for schools for both the boys and girls had not progressed very much before he arrived, Edwards was particularly interested in establishing a system of instruction that would insure the greatest success. ${ }^{8}$ Today, New England's grammar and preparatory school system, founded in colonial times, is viewed by historians as one of the American puritans' chief legacies. But if we were to judge it by Edwards' description, we might hesitate about this estimation. For his part, he defined a "successful" system largely as anything that schools among the English were not. The mission school "should be free from the gross defects of the ordinary method of teaching among the English," he asserted. Children in English schools were "habituated to learning without understanding," that is, they were taught to read only through the habit of "making such and such sounds, on the sight of such and such letters," and so without comprehension. "In like manner they are taught their catechism," Edwards opined, "saying over the words by rote, which they began to say, before they were capable of easily and readily comprehending them." Sounds, and ideas that were associated with them, were not connected.

Whether in isolation, or as a result of consultations with his peers and reading in current authors on education, such as John Locke, Edwards advocated a different kind of pedagogical episteme. Instead of implementing learning primarily by rote or memorization, as his father had, he envisioned a dialogic, Socratic, or, as Edwards called it, "familiar" method that drew on new theories of learning as well as on tried and true forms such as the medieval scholastic disputation. " "I]n these boarding schools, the children should never read a lesson, without the master or mistress taking a care, that the child be made to attend to, and understand, the meaning of the words and sentences which it reads." More importantly, "the child should be taught to understand things, as well as words." After reading something, the teacher should explain not only the words and phrases, but "the things which the lesson treats of

7 Quotes in this section from Edwards' letter can be found in Claghorn 1998:406-14.

8 Space prohibits a rehearsal of the saga of the boarding schools at Stockbridge, which is long and convoluted. See Marsden 2003:375-94.

9 Locke, Some Thoughts Concerning Education (London, 1690), was in the Dummer Collection (Mooney 2001:A41) and was cited by Edwards in "Miscellanies," no. 1210, from George Turnbull, Principles of Moral and Christian Philosophy (2 vols., London, 1740). On Edwards' acquaintance with the scholastic disputation, see his M. A. Quaestio, in Minkema 1997:47-66. 
should be, in a familiar manner, opened to the child's understanding." This should in turn open a conversation and dialogue between teacher and student, with "familiar questions" that encourage the child "to speak freely, and in his turn also to ask questions, for the resolution of his own doubts." So too when working with "printed catechisms," this principle of exchange, of question and answer, of encouraging inquiry on the part of the student, should prevail. "[Q]uestions should be asked them from time to time," Edwards continued, "in the same familiar manner, as they are asked questions commonly about their ordinary affairs." Eventually, this would inculcate "the habit of conversation on divine things," and the child "divested of that shyness and backwardness discovered in children, to converse on such topics with their superiors." While Edwards may have been no advocate of an open classroom, his idea of teaching was more open than the traditional relation between instructor and student. Interestingly, one of the chief components of his system was "familiar discourse," which seems to have consisted for the most part in telling stories the same shift we see in his sermonic delivery upon coming to Stockbridge.

Note, too, Edwards' stress on "understanding." In his treatises, particularly that on freedom of will, he identified understanding as the chief cognitive faculty over against will. Understanding for him was the faculty whereby a person judged, discerned, and speculated. He defined it in "a large sense, as including the whole faculty of perception or apprehension, and not merely what is called reason or judgment." ${ }^{10}$ Knowledge was acquired and, thereby, choices informed, through understanding. So, behind his theories about teaching Indian children lurked his anthropology. With the understanding thus exercised, Edwards went on to say, "the child's learning will be rendered pleasant, entertaining and profitable," increasing knowledge and improving the capacity to reason. No longer "a dull, wearisome task, without any suitable pleasure or benefit," learning would instead be an object of desire, and the child will acquire "a regularly increasing appetite for it."

Another way in which Edwards judged "the common methods of instruction in New England" to be "grossly defective," was that instructors did not give "a short general scheme of the scriptural history" to their charges. Here we see the centrality of religious content in Edwards' view of education and individual development, both intellectual and spiritual. From the general heads of this scriptural scheme, the teacher could "entertain them, in like familiar discourse, with the particular stories of the Scriptures, sometimes with one story, and then with another, before they can obtain the knowledge of them themselves, by reading." In this way, the whole child is addressed, as Edwards put it, "informing of the child's understanding, influencing his heart, and directing its practice."

10 Edwards, Freedom of the Will, in Ramsey 1957:148. 
Once they had learned to read their Bibles with enough proficiency, children "might be set to read a particular story, sometimes one, and sometimes another, diligently observing it." After reading, the master or mistress could inquire "concerning the particulars of the story, to see that the child has taken good notice, and is able to give an account of it." Edwards became quite ambitious for his Stockbridge children. They were to be immersed in learning the connections between the Old and New Testaments, ecclesiastical history, chronology, and the geography of the Middle East.

Edwards was further innovative in arguing that these methods were to be taken with both boys and girls. This was going against custom, in which daughters were given only a minimal education or, if from an elite or upwardly mobile middle class family, perhaps attended a dame school for a time to learn domestic skills such as painting, sewing, and embroidery. Edwards' inclusivism on this count was due in part to his own upbringing in his parents' home school with ten well-educated sisters, but also seems to have reflected a commonly held, though little studied, view of co-education within provincial gentry culture. ${ }^{11}$

However, having pleased modern readers with some hint of gender equality, Edwards shows himself to a person of his times. He points out that these measures "would serve, the more speedily and effectually, to change the taste of Indians, and to bring them off from their barbarism and brutality, to a relish for those things which belong to civilization and refinement." It is important to understand that conventional European wisdom held that "Christian" meant "civilized," and "civilized" meant European in lifestyle, clothing, housing, manners, and especially speech. At Stockbridge, the Indians were to be weaned from their native tongues and made to speak English. "[l]t is necessary that the children should be taught the English tongue; and indeed this is the most absolute necessity, on almost every account. Indian languages are extremely barbarous and barren, and very ill-fitted for communicating things moral divine, or even things speculative and abstract. In short, they are wholly unfit for a people possessed of civilization, knowledge and refinement." Towards this conventional end, Edwards again proposed an innovative step: mixing English and Indian students together.

Having mixed-race classes may have been Edwards' goal for the Stockbridge mission, but he also saw the practical need for English missionary-teachers to be multilingual. Thus, he advocated that missionary candidates such as Job Strong and Elihu Spencer, two protégés of Edwards, learn Indian dialects for their work among the western tribes (i.e. in New York and Pennsylvania). Also, Edwards preened one of his sons, Jonathan Jr., for missionary labors. The family moved to Stockbridge when Jonathan Jr. was

11 On female education in colonial British America, see Hayes 1996. 
only five years old, so he grew up speaking several Indian dialects, played with Indian children, and indeed for a time apparently spoke Mahican better than English. Edwards Sr.'s hopes for his son did not pan out; the son liked refined life too much to live at a frontier post or to itinerate from camp to camp like a David Brainerd. However, he did keep up his acquaintances in the missionary fields, and, in 1788 , published a pamphlet comparing several Indian dialects with Hebrew, on the theory that Indians were descendants of the lost tribes of Israel (Edwards Jr. 1788).

Yet another intriguing aspect of Edwards Sr.'s view of "Christian education" was his proposal to teach the students to sing. "Music, especially sacred music, has a powerful efficacy to soften the heart into tenderness, to harmonize the affections, and to give the mind a relish for objects of a superior character." His emphasis on the role of music was a carry-over from his personal and his family life. In his private devotions, he sang and chanted his meditations (Edwards, "Personal Narrative," in Claghorn 1998:794). Family devotions in his home included psalm and hymn singing, and there were instruments in the Edwards home as well (Hopkins 1765:46-47). Also, music points to Edwards' aesthetics, which was a central part of his philosophical theology. He portrayed the Trinity in musical terms, and saw harmony as part of the excellency and beauty of the divine and of creation. ${ }^{12}$

\section{A CATALOGUE OF BOOKS FOR INDIAN CHILDREN}

Teaching inevitably involves books, so which texts would Edwards have assigned for children? In a 1757 letter to one of his former students, Joseph Bellamy, who became the long-time minister and teacher at Bethlehem, Connecticut, Edwards included a "Catalogue of Books" (Letter of 12 Feb. 1757, in Claghorn 1998:700-1). These books were to serve as a syllabus for the several Stockbridge Indian boys who were then staying at Bellamy's house. They had come there through a combination of circumstances: as a safety measure because of the danger posed to Stockbridge by the war that was then going on; because by then the boarding schools had been scuttled, and the buildings themselves burned down, through conflict between Edwards and the Williams clan; and because Edwards was able to get them away from their parents and peers, whom he considered a detrimental influence.

The "Catalogue" that Edwards sent to Bellamy does not exist, but it may have been the same as the one that he sent to Pepperrell six years earlier (Thuesen 2008:44-45, 361-62). That list includes, to begin, a dictionary - but not just any dictionary. Only the best would do, and for this Edwards put at the top of the list Samuel Johnson's A dictionary of the English language.

12 See Delattre 1968, Mitchell 2003, and Pauw 2003. 
This two-volume work, which became the standard until the publication of the Oxford English Dictionary, was printed in London in 1755, though announcements heralding its publication had appeared as much as eight years earlier. Edwards also included Thomas Dyche, The spelling dictionary; or, A collection of all the common word and proper names made use of in the English tongue (London, 1723, rev. ed., 1725). To supplement, Edwards had recourse to an array of English (and should any student show a proficiency, Latin and Greek) grammars in his own and in his father's libraries.

So much for the basics of the English language. For the sciences, Edwards chose Andrew Baxter's Matho; sive, Cosmotheoria puerilis (Edinburgh, 1738), which was translated and printed in London in 1740 and 1745. The work is formatted as a dialogue, an increasingly popular genre in the eighteenth century. One of the figures is a fictional boy asking questions about philosophy and science. We can see where Edwards would have liked this approach, because it bears out his point to Pepperrell that a dialogic or "familiar" method of teaching was the most effective.

Edwards customarily drew up drafts of letters to important figures, and in his draft notes for his letter to Pepperrell, only recently made available,$^{13}$ he wrote that he would have the children taught the "extent, boundaries, capital cities, etc., of the several countries, then teach 'em a little of the history and present state of each of [the] countries". The two texts he suggested were Thomas Salmon's A new geographical and historical grammar (London, 1749) and John Fransham's The world in miniature; or, The entertaining traveler (London, 1740). This latter work professed, by its lengthy title, to give an account "of everything necessary and curious" of all the various countries of the world. In addition, John Chamberlayne and Edward Chamberlayne's Magnae Britanniae notita; or, The present state of Great-Britain (London, 1708), which also had "divers remarks upon the antient state" of the kingdom, reflects Edwards' desire to anglicize the natives. These works highlight the visual nature of education for Edwards, not only in observing natural phenomena, but, in the case of geography, using maps. In a time when printed maps were expensive, the inventory of Edwards' estate lists a dozen maps of various sizes (Park 1876:446).

For history, Edwards chose a piece of a much larger, renowned work by Nathaniel Lardner, an English Presbyterian tutor, chaplain, and preacher: the massive Credibility of the Gospel history, which appeared in a total of seventeen volumes from 1727 to 1757 . For the purposes of teaching the Indian children, Edwards contented himself with the twelfth volume of part 2

13 See the transcript of Jonathan Edwards to Pepperrell, 28 Nov. 1751, Letter 135, in the WJEO version of vol. 16. 
(1755), which provided a "recapitulation" or summary of the previous eleven volumes.

Edwards' other area of required reading was apologies for Christianity. Chief among them Gilbert Burnet's, $A$ defence of natural and revealed religion. This was an installment of a lecture series, which attracted some of the best religious minds in England, was established by the English physicist Robert Boyle to defend Christianity. Edwards cited the four-volume, 1737 edition, but knew of subsequent editions that were better. Another work in this vein was The divine legation of Moses demonstrated of William Warburton, an Anglican churchman (2 vols., London, 1738-41). In this famous treatise, Warburton turned the tables on deist critics of the divine authorship of the books of Moses by arguing that the lack of any mention of a future state in the Pentateuch paradoxically proved their divinity. Edwards wanted to have the students focus on the "fourth volume" of this work: "The nature of the Jewish Theocracy explained: And the Doctrine of a future State proved not to be in, nor to make Part of the Mosaic Dispensation," and "An Examination of all the Texts brought from the Old and New Testaments to prove a future State of Rewards and Punishments did make Part of the Mosaic Dispensation." Finally, in his letter to Bellamy, Edwards wrote that he should have inserted one more title in the list: Irish Presbyterian divine John Leland's An answer to a late book intituled, Christianity as old as the creation (Dublin, 1733), a response to Matthew Tindal's infamous critique of Christianity.

And this was his syllabus for Indian children! Clearly, Edwards was a demanding teacher, and he set the native children to high standards. The titles he chose reflect his desire to have the latest, and best, in the respective subjects - a practice he followed in his own reading and study habits as well.

\section{THE INDIANS AT BETHLEHEM}

When, in 1756, Bellamy agreed to assist Edwards by taking in and teaching several Indian boys, he may not have been prepared for the trouble they would pose. In May of that year he wrote to Edwards:

The Indian boys grow more and more easy and content, but they love play too well, are very ignorant, and very stupid as to things of religion; and in arithmetic, when I would teach them anything that is a little difficult, they soon are discouraged, and don't love to try. So I take them off and put them to writing again, designing by little and little to get them along. They will not endure hardship and bend their minds to business like English boys. It seems they were never learnt their catechism; shall 
I learn them? I have got 3 Bibles, but not given them to the boys, they are so ignorant. ${ }^{14}$

Clearly, the agenda that Edwards had laid out to Pepperrell was proving somewhat unrealistic. Nonetheless, he urged Bellamy on:

I should be glad that you would use thorough endeavors with the boys to teach 'em arithmetic; let there be a thorough trial with them whether they can learn. If they can't, I shall think it is hardly worth the while to send 'em abroad under the notion of giving them an extraordinary education. I would also propose the following things, viz., that pains be taken with 'em to teach 'em the English tongue, to learn 'em the meaning of English words and what the name of everything is in English; and as far as may be, teach 'em the meaning of the English that they read, and make 'em turn it into Indian. And that they be taught to pray; that you write out for them various forms of prayer, and make 'em understand them, and turn them often into Indian. And to teach 'em the [Westminster] Assembly's [Shorter] Catechism, and endeavor as far as may be to make 'em to understand it. To ask 'em questions of the Scripture history, not only the lessons they read, but of the main things in the general history of the Bible in their order. I wish you would send. to [New] York to . . . get some plain maps of the land of Canaan, and places adjacent (Letter of [June 1756], in Claghorn 1998:688-89).

In the end, the efforts by Edwards, Woodbridge, and Hawley at Stockbridge, and of Bellamy at Bethlehem, to get the Indians to "bend their minds to business like English boys" largely failed, both a symbol and a victim of Anglo-Indian colonial encounters.

\section{QUESTIONS FOR YOUNG PEOPLE}

Among Edwards' manuscripts is a little-referenced set of "Questions for Young People," which gives us a glimpse of how he functioned as a bible instructor at Northampton. Incidentally, "young people," for Edwards, were individuals from fifteen to twenty-five years old. This set of questions was for young men; a similar list for young women, if there ever was one, has not survived. In the list, a total of sixty-six names appear of individuals born between 1712 and 1728 - in other words, those who came of age and joined the church during the Connecticut Valley revival of 1734-35. ${ }^{15}$ These questions, a hundred and fifty of which have survived, were drawn from Scripture to test the catechists'

14 Joseph Bellamy to Edwards, 31 May 1756, ANTS, f. 1756-59A, \#8; transcription available in WJEO 32, Letter B115.

15 On the generational nature of the revivals, see Tracy 1980:91-122. 
knowledge of the scripture history, their power to relate one passage to another, and their reasoning ability.

Edwards constructed the list with a certain format. Here are a couple of random examples, showing how he stated the question, provided the scriptural reference that answered it, and wrote the name of the person to whom it was assigned:

4. Where was the place where the tabernacle that Moses made in the wilderness was kept after the children of Israel were come up out [of] Egypt and settled in Canaan? Josh. 18:1. (Simeon Root)

48. How often did the children of Israel come to the Red Sea after they departed from Mt. Sinai before they came to Canaan? Num. 6:33, 35; Num. 6:14, 25; Deut. 2:1, I Kgs. 9:26. (Joseph Parsons)

As these samples suggest, most of the questions relate to the Old Testament, which covers a longer span of history. More generally, however, Edwards could formulate a theme, such as:

Questions that must be answered by the knowledge of the harmony of the evangelists.

And still others could relate explicitly to sermons that the examinees would have heard their pastor preach - perhaps to make sure they were listening attentively:

52. Questions concerning the circumstances of Christ's last sufferings, out of my discourse of the sufferings of Christ.

The "discourse" he referred to was most likely the one on Is. 53:3, with the doctrine, "Our Lord Jesus Christ, when upon earth, met with abundance of contempt and reproach," preached around the turn of 1729 and recounting the final events of Christ's life. ${ }^{16}$ An even more expansive approach is represented in the following entry, at the very end of the list, where the manuscript is battered:

[138. A]T ANOTHER TIME, put the [y]oung people upon giving [rea] sons of this or that, and proving such [and s] uch things by argument. [Also,] what arguments can you bring [for them], or how do you prove

16 Sermon on Is. 53:3 (no. 93); transcript available in WJEO 43. 
[them; wh]at can you mention that proves [them; what can] you give for this or that?

Even here, where students were to martial their reasons for "this or that," we see that Edwards employed a variation of his "familiar" method. But Edwards had other means to teach and counsel young people. One was "conferences," segregated into male and female, at which the pastor sometimes, though not always, supervised and held forth. These special meetings, adapted from the collegia pietatis developed in Europe among the Pietists, provided opportunities for Edwards to address directly the morals of the town's young people, which he saw as deteriorating at a steady pace. Here, young men and women would come together to "read and pray, and sing praises, and to converse of the things of God and another world" (Goen 1972;329). As with children, Edwards also crafted sermons specifically for young people; in fact, there are more sermons in his corpus directed at this group than any other age cohort. ${ }^{17}$ Having focused on the young people as the vanguard of the Connecticut Valley Revival of the mid-1730s, Edwards was particularly

17 Sermons to young people include: no. 274, on Job 20:11, "Many persons never get rid of the guilt of the sins of their youth, but it attends them to their graves and goes with them into eternity," March 1733, "To the young people at a private meeting" (WJEO 48); no. 323, on Prov. 24:13-14, "The directest way that young people can take to spend their youth pleasantly, is to walk in the ways of virtue and piety," May 1734, published as Youth and the Pleasures of Piety, in Lesser 2001:78-90; no. 493, on Prov. 7:7, "Those young people that spend their youth in sin and vanity act as those that are void of understanding," Nov. 1738; no. 560, on Eph. 4:29, "Professing Christians, when they meet together, should avoid all corrupt discourse one with another and should practice that whereby they may promote the good of each others' souls," July 1740, "For a meeting of young people," published as The Danger of Corrupt Communication Among Young People, in Stout and Hatch 2003:158-66; no. 593, on Job 14:2, "'He cometh forth like a flower and is cut down.' ... The use . . . to exhort and beseech the young people that are here present to get ready for death," Feb. 1741, Funeral, "To a private meeting of young people after Billy Sheldon's death . . . Afterwards preached . . on occasion of the death of my daughter Jerusha, Feb. 21, 1748," published as Youth is Like a Flower That Is Cut Down, in Stout and Hatch 2003:319-38; no. 761, on Ps. 144:12, "Tis a peculiarly lovely and pleasant sight to behold young people walking in the ways of virtue and piety," Nov. 1744, Quarterly lecture, published as The Beauty of Piety in Youth in Kimnach 2006:103-10; no. 845, on Is. 1:2. "I shall discourse from the words at this time, 1. By considering how we are the children of God. 2. [How] God has nourished and brought us up as children. 3. How heinous it is for such to rebel against God," Nov. 1746, "Lecture to young people," published as Rebellion in Israel in Kimnach 2006:155-63; no. 856, on Eccles. 11:9-10, "When young people will follow their own youthful disposition and indulge themselves in vain mirth or pleasure, God will surely bring 'em into judgment for those things and they will surely end in sorrow," Feb. 1747 (WJEO 65). 
earnest with this group when he saw their piety decline and their behavior slide into viciousness. This age, when the will was most flexible, he saw as the most important for the establishment of virtuous character and disciplined habits that would last with a person through their entire life.

\section{TUTORSHIP AT YALE}

From young people in a parish setting, we now move to Edwards' dealings as an instructor of baccalaureate students - still young people, to be sure, but at a more intensive and sophisticated level of instruction. For Edwards' first experience at this level, we must go back to when he was still a young person himself: the period from June 1724 to September 1726, when he was a tutor at Yale College. This was immediately after the defection of rector Timothy Cutler and several tutors and area ministers to the Church of England in 1723, so the college was understaffed and on shaky ground.

We know that Edwards spent at least some of his time reading in the college library, lengthening his catalog of books and beginning or adding to notebooks, and that the tutorship was a low point in Edwards' spiritual life. But what did he teach? We have little direct knowledge, but one source tells us something. In 1729, John Sargeant, who later would be Edwards' predecessor at the Stockbridge mission, gave the valedictorian oration at commencement. Though by this time Edwards was ensconced at Northampton, and the college had a new rector, Elisha Williams, Sargeant and his classmates had been tutored as freshmen and possibly sophomores by Edwards, who attended the ceremony. Sargeant's language, in keeping with valedictories, is deliberately florid, but from it we learn that Edwards taught Rhetoric--"the art of speaking" - Mathematics - "the mysteries of number and mathematical quantity" Astronomy - "the magnitudes of the globes that compose our system" - and Natural Philosophy - "you have led us into the deepest recesses of nature, and disclosed her most intricate contrivances" (Sargeant 1882:22-24). Not surprisingly, these were also the very subjects he was delving into in his private notebooks, such as the notes on "Natural Philosophy" and on "The Mind."

\section{PRINCETON}

Next, we must again jump forward in time, to the last months of Edwards' life. Perhaps the most famous document relating to his Princeton period is his lengthy, detailed, and remarkably self-disclosing letter to the College Trustees, in response to their offer of the presidency. Edwards demurred, giving them a wonderfully onomatopoeic description of his body's "constitution" - with its 
"flaccid solids, vapid, sizy and scarce fluids, and a low tide of spirits" - and a fulsome summary of his unfinished "great works." What is less frequently noticed in the letter is Edwards' estimation of himself in scholarly terms. First, he confessed, "I am . . . deficient in some parts of learning, particularly in algebra, and the higher parts of mathematics, and in the Greek classics; my Greek learning having been chiefly in the New Testament." Next, he described his "method of study" as consisting "very much in writing." Samuel Hopkins confirms this, when he states that Edwards thought "with his pen in his hand" (Hopkins 1765:44). Also, he was quite disingenuous - some might say he was negotiating terms - in setting limits to what would be expected of him as president. He would not "go through the same course of employ" as his late predecessor and son-in-law Aaron Burr, Sr. - especially seeing that his rigorous and rather hectic schedule had been the death of him. Rather, Edwards offered,

I should be willing to take upon me the work of a president, so far as it consists in the general inspection of the whole society and subservient to the school, as to their order and methods of study and instruction, assisting myself in immediate instruction in the arts and sciences (as discretion should direct and occasion serve, and the state of things require), especially the senior class: and added to all, should be willing to do the whole work of a professor of divinity, in public and private lectures, proposing questions to be answered, and some to be discussed in writing and free conversation, in meetings of graduates and others, appointed in proper seasons for these ends. It would be now out of my way, to spend time, in a constant teaching of the languages; unless it be the Hebrew tongue, which I should be willing to improve myself in, by instructing others. ${ }^{18}$

From the biography of Edwards by his student and colleague Hopkins, we learn that Edwards "preached in the college hall Sabbath after Sabbath, to the great acceptance of his hearers." In Edwards' extant sermon corpus, there are only three sermons that can be identified as having been preached at Princeton. The first was delivered in July 1752, when Edwards was visiting there following his daughter Esther's marriage to Rev. Aaron Burr, then the college's president. ${ }^{19}$ The sermon, on Is. 9:6, was originally written and

18 Edwards to the Trustees of the College of New Jersey, Oct. 19, 1757, in Claghorn 1998:726, 729. For an early engagement of Edwards with Hebrew during his college years, see his parsing, in Latin, of Ps. 1, ANTS, f. ND5.11; and on his interest in Hebrew late in life, see the MS "Hebrew Idioms," Gen. Mss., 151, f. 1211, Beinecke Rare Book and Manuscript Library, Yale University.

19 Edwards, MS sermon no. 926, on Is. 9:6: "Christ, above all persons that ever did or will appear in the world, is the most eminent counselor," Mar. 1749, repreached July 1752 (WJEO 67). 
delivered in Northampton in 1737, but Edwards wrote a special Application for "those members of the college in this place, who are expecting this week to receive the honor of the society." Treating the theme of Christ as the eminent Counselor, the best Teacher, Edwards exhorted the students to make sure that in the "public business" of the ministry for which they had been prepared, that they ensure that they have Christ as their counselor. Not content with addressing only the graduating students, Edwards concluded,

Lastly, I would apply the exhortation to the students in general, who are members of this seminary of learning, and to those who are instructed in the grammar school in this place. Let me beseech you, dear children and youth, as you would regard the interest of your precious and immortal souls, to hearken to the advice of that great Counselor which you have learnt, and whose advice in many of the more important articles of it has been set before you this day.

Only two sermons are marked by Edwards as having been delivered (repreached, actually) in February 1758. The first is on II Pet. 1:19, with the doctrine, "Divine revelation is like a light that shines in a dark place." ${ }^{20}$ For the students, Edwards emphasized the role of prophecy as the word of truth "in the midst of heretics and apostates." He engaged in a grand survey of world religions, from Deism to Catholicism to Islam, as instances of cultures that are devoid of divine revelation. Scripture, he concluded, is the "greatest and most important and most divine truth." The other sermon is on Jude 6, which proclaimed that "the day of judgment will be a great day." ${ }^{21}$ In a grand panoply, Edwards described the final judgment, from the manifestation of God's glory in its many aspects to the "grand assembly" that will be gathered before the judgment seat to the cessation of the earth. From comparative religions (albeit through the filter of protestant triumphalism) to the conflagration, Edwards probably saw these sermons as educational as much as inspirational, because of their basis in his reading of the Bible.

\section{THEOLOGICAL QUESTIONS}

When recounting Edwards' time at Princeton, Hopkins stated that, besides preaching in the college hall, he gave out

some questions in divinity to the senior class, to be answered before him; each one having opportunity to study and write what he thought proper

20 Edwards, MS sermon no. 443, originally preached at Northampton, Aug. 1737 (WJEO 52).

21 Edwards, MS sermon no. 742, originally preached at Northampton May 1744, repreached July 8, 1744, at Southampton (Judd Diary); Jan. 1754 to the Stockbridge Indians; and Feb. 1758 (WJEO 62). 
upon them. When they came together answer them, they found so much entertainment and profit by it, especially by the light and instruction Mr. Edwards communicated in what he said upon the questions, when they had delivered what they had to say, that they spoke of it with the greatest satisfaction and wonder (Hopkins 1765:24-25).

Two observations can be made about this recollection. First, we see Edwards again employing his "familiar" method, in which he had the young scholars write up their own thoughts first, and then engage with him in dialogue about them. Secondly, we can in all likelihood identify these "questions in divinity" that Edwards dispensed as coming from two extant compilations. One is a manuscript entitled "Questions on Theological Subjects" (WJEO 39), which contains a total of fifty-three problems in doctrine and theology, set down in a notebook constructed in 1746 or later. These are a step up in complexity from the "Questions for Young People." At this point in his life, Edwards was attracting more ministerial candidates into his home, which may explain why he took the time to compose this document. These questions don't proceed in the order dictated by systematic theology, but, much like the "Miscellanies," jump around from topic to topic, though with an emphasis on the nature of God - for example, "In what sense is God said to be necessarily existent?" - and on aspects of soteriology, as represented by the query, "In what sense was faith in Jesus Christ necessary in order to salvation under the old testament"? The issues reflect his ongoing concerns about Arminianism, including divine foreknowledge, freedom of will, the end of creation, and original sin - all topics on which he working in the 1740s and on which he eventually published. However, none of the questions relate to the nature of the church, a topic he was rather forced into writing about because of the distasteful "qualifications controversy" that culminated in his dismissal - which may explain the lack of attention to ecclesiology.

The other list is preserved in a pamphlet, printed in Providence, Rhode Island, in 1822, entitled The Theological Questions of President Edwards, Senior, and Dr. Edwards, His Son.22 A later reprinting of these questions in the prominent New Divinity journal, Bibliotheca Sacra, in 1882 (pp. 367-81), indicated they were for "their pupils in theology." As opposed to the "Questions on Theological Subjects," the questions here are arranged systematically, starting with the nature of God and ending with the church.

22 The origin of this pamphlet is something of a mystery, but we can speculate that Sereno Dwight, Edwards' great-grandson, had a hand in it, since at this time he was preparing the 10-volume edition of Edwards' Works published in New York, 1829. 
1. How does it appear that something has existed from Eternity?

10. How do you prove that the persons in the Trinity are one God?

19. Why did God decree sin?

44. In what manner did Christ atone for $\sin$ ?

83. What is the nature of the Christian Church?

Some of these questions reflect the "improvements" that Hopkins gave to some of Edwards' teachings, such as:

65. What is the essence of true virtue, or holiness?

67. Is not self love the root of all virtue?

68. Do not the unregenerate desire to be regenerated and can they not properly pray for regenerating grace?

Edwards, Sr.'s list amounts to 90 querae. Interestingly, while some questions in the lists of father and son deal with the same general topic (e.g. the nature of the Sabbath), none of them correlate exactly.

\section{THE "MISCELLANIES" AS AN EDUCATIONAL TOOL}

In the list of "Questions for Young People" of Northampton, there is an intriguing entry:

$118 \mathrm{~b} .{ }^{\dagger}$ What memorable transaction was there amongst the Israelites, at that time of the year and month when the Feast of Weeks, or Pentecost, was kept, in commemoration of which that festival seems therefore to be appointed? See Mather on Types, p. 424 at top; "Miscellanies," first volume in quarto, pp. 26-27. ${ }^{23}$

This question suggests that the students were given access to Edwards' library - the title, Samuel Mather's Figures or Types of the Old Testament, was but one of several hundred from which to choose - and possibly to his personal manuscripts. At the very least, Edwards was using his private notebooks as a

23 Mather 1705: 424: "Now they came out at the Passover, which was on the fourteenth Day of the first Month; from whence, if you reckon fifty Days from the sixteenth Day of the first Month, it will bring you to the sixth Day of the third Month, in which they received the Law at Mount Sinai, the Memorial whereof was celebrated by this Feast." 
resource. Ava Chamberlain has speculated that the "Miscellanies" were "quasipublic" documents that Edwards made available to his students (Chamberlain 2000:9-10). His reference is to the first section of "Miscellanies" no. 691, on "Sabbath, Lord's Day" (Chamberlain 2000:262). The pedagogical component of the "Miscellanies" is further confirmed by the "Questions on Theological Subjects," which contains several loci that cite "Miscellanies" entries.

We know, too, that Samuel Hopkins utilized the "Miscellanies" as well as other of Edwards' notebooks. Edwards had left his manuscripts in Hopkins' care when he went to Princeton. Following Edwards' death, Hopkins had Jonathan Jr. peruse them when he was studying with Hopkins in 1765-66 perhaps a method to which he himself had been introduced when studying under Edwards Sr.

\section{EDWARDS ON MINISTERS' EDUCATION AND AS TEACHERS}

Edwards maintained an informal parsonage seminary, in which he took in recently graduated students (mostly from Yale) and furthered their intellectual and practical training for the ministry. Such "schools of the prophets" were increasingly popular in colonial New England (Gambrell 1937, Warch 1973, Endy Jr. 1984). The exact number of students that Edwards had is unknown. Joseph Bellamy and Samuel Hopkins are the most famous. Other, less known individuals who studied with Edwards, or at least spent some time in his home, included John Searl, Northampton native and pastor successively of Sharon, Connecticut, Stoneham, Massachusetts, and Royalton, Vermont; Job Strong, another son of Northampton and pastor of Portsmouth, New Hampshire; Elihu Spencer, who with Strong spent the summer of 1749 at the Edwards parsonage, served as a missionary to the Oneidas, married Edwards' daughter Sarah, and served a variety of churches in New York, New Jersey, and Delaware; Daniel Brinsmade, pastor of Washington, Connecticut, for much of the latter half of the eighteenth century; and former Bellamy student Gideon Hawley, who after serving as teacher at Stockbridge under Edwards during the early 1750s, was the missionary to the Mashpee Indians on Cape Cod for nearly half a century.

Beginning in the early 1740 s, Edwards, because of his prestigious position at Northampton and his reputation as a revivalist and theologian, was called upon increasingly to preach at ordination services and on the nature of the ministry. ${ }^{24}$ These sermons, as Wilson Kimnach characterizes them, convey a

24 Ordination and installation sermons by JE include those for: Jonathan Judd, at Southampton, Massachusetts, published as The Great Concern of a Watchman for 
heroic sense of the minister's calling, emphasizing the sacrifices that must be made and the stands that the minister must take for truth (Kimnach 2006:1419). Some of them, too, touched on the issue of ministers as teachers. Here we find two senses of "teacher." In One Great End in God's Appointing the Ministry - Edwards' defense of his right to preach what he wished during the qualifications controversy of 1748-50 - he used the term in the broadest sense of "guides" and "shepherds" who study the Scriptures (Kimnach 2006:44356). So too in his Farewell Sermon, when advising his former parishioners of Northampton on the kind of minister they should seek, he told them (with no small degree of self-justification) to keep in mind that

\begin{abstract}
Ministers are set as guides and teachers, and are represented in Scripture as lights set up in the churches; and in the present state meet their people from time to time in order to instruct and enlighten them, to correct their mistakes, and to be a voice behind them, when they turn aside to the right hand or the left, saying, "This is the way, walk in it"; to evince and confirm the truth by exhibiting the proper evidences of it, and to refute errors and corrupt opinions, to convince the erroneous and establish the doubting (Kimnach 2006:466).
\end{abstract}

More specifically, though, Edwards also described ministers as instructors of church members. In True Excellency, preached for the ordination of Robert Abercrombie at Pelham, Massachusetts, in 1744, he stressed the learnedness of the minister:

He must be one that is able to teach, not one that is raw, ignorant or unlearned, and but little versed in the things that he is to teach others; not a novice, or one that is unskillful in the word of righteousness; he must be one that is well studied in divinity, well acquainted with the

Souls (Boston, 1743); Robert Abercrombie, at Pelham, Massachusetts, published as The True Excellency of a Minister of the Gospel (Boston, 1744); Samuel Buell, at Easthampton, Long Island, New York, published as The Church's Marriage to Her Sons, and to Her God (Boston, 1746); Job Strong, at Portsmouth, New Hampshire, published as Christ the Great Example of Gospel Ministers (Boston, 1750); Edward Billing, at Greenfield, Massachusetts, 1754, and Cornelius Jones, at Sandisfield, Massachusetts, published as Christ's Sacrifice An Inducement To His Ministers; Joseph Ashley, at Sunderland, Massachusetts, published as Sons of Oil, Heavenly Lights. All of these are collected in Kimnach 2006; other ordination sermons, published after Edwards' death, are in Bailey and Wills 2002: David White, at Lambstown (Hardwick), Massachusetts, 1736, published as The Minister Before the Judgment Seat of Christ, Edward Billing, at Cold Spring, Massachusetts, 1740, published as Ministers Not to Preach Their Own Wisdom But the Word of God; Chester Williams, at Hadley, Massachusetts, 1741, published as Pastor and People Must Look to God. 
written Word of God, mighty in the Scriptures, and able to instruct and convince gainsayers (Kimnach 2006:92-93).

\subsection{Joseph Bellamy}

In 1736, after graduating from Yale College, Joseph Bellamy, as was customary in colonial New England, went to pursue individual study. After a false start with one minister, he gravitated to Edwards. Like several of his classmates, Bellamy was from a rural, middling background and was attracted to the evangelical religion that Edwards dispensed. It's likely he came to Edwards because of his recent regional (soon to be international) fame due to the Connecticut Valley revivals, and because of Bellamy's ambition to be a preacher in the same vein.

In a folio ledger book over some twenty pages or so, Bellamy scrawled notes from readings assigned by Edwards, as well as what appear to be some incidental compositions of his own. Without the in-depth study that this notebook deserves, it's difficult to draw any direct correlations between Edwards' interests at this time and Bellamy's notes, but we can make some preliminary observations. Several entries line up, not in exact wording but in subject matter, with Edwards' "Miscellanies" from this period, roughly entry nos. 675-710. For example, Bellamy has an entry on the unpardonable sin the sin against the Holy Ghost - a theme Edwards pursued in "Miscellanies" nos. 703 and $706 .{ }^{25}$ The very next topic Bellamy takes up is baptism, which Edwards likewise explored in no. 694. Furthermore, Bellamy has a writing exercise on the question, "Will there be employment in heaven?" Heaven is the topic of "Miscellanies" nos. 681 and 701. Finally, as Mark Valeri has noted, some of Bellamy's reading notes are similar in tone to Edwards' developing vision of the history of the work of redemption. ${ }^{26}$

Bellamy either cited or directly quoted from several books, providing a view of what Edwards recommended to his first independent student - or what in Edwards' library caught Bellamy's eye. The primary text was by John Edwards, "the last of the English Calvinists," entitled Theologia reformata: or, the body and substance of the Christian religion, comprised in distinct discourses or treatises (London, 1713). As the copious title page informs us, it was "Fram'd as to be useful not only to Profess'd Student in Divinity, but to all that are Lovers of Divine Knowledge, and desire to make farther Proficiency in it." Not only did it treat the Apostle's Creed, the Lord's Prayer, and the Ten

25 MS, "Joseph Bellamy H. B. 1736," Yale Divinity School, Special Collections, pp. 3-4. I have made use of a transcript kindly provided by Mark Valeri of Union Theological Seminary in Virginia.

26 Ibid., p. 13. 
Commandments, but provided an "Antidote" against "dangerous Opinions" ranging from Papists and Pelagians to Deists and libertines. Thus, the work was a synopsis of the main points of Reformed religion but also a polemic against contrary views. This, as well as other less cited books in Bellamy's notebook were also in Edwards' library or were cited by him in his writings: Robert Jenkin's The Reasonable and Certainty of the Christian Religion (2 vols., London, 1698); Samuel Willard's A compleat body of divinity in two hundred and fifty expository lectures on the Assembly's Shorter Catechism (Boston, 1726); Sir Walter Raleigh, The historie of the world (London, 1614); Humphrey Ditton, A Discourse Concerning the Resurrection of Jesus Christ (London, 1712, though Edwards used the third edition, 1722); and John Anderson's A defence of the church-government, faith, worship \& spirit of the Presbyterians (Glasgow, 1714).

Bellamy's notebook evolved organically. It began, in the first part, as brief statements of major doctrinal loci or theological topics, indexed to the discussion of them in Theologia Reformata. Later entries were short essays and longer quotes. In other words, it started as a traditional commonplace book and became a version of his mentor's "Miscellanies," writ small.

One means of training young men for the ministry among the New Divinity, as we have seen with Edwards, was for tutors to compile a list of theological questions that they could assign. In 1756, Bellamy wrote to Samuel Hopkins proposing that they develop and publish their own list "to assist young Students in the Study of Divinity."27 These "Philosophems," as Bellamy called them, never came to fruition, but the habit of passing along, and adding to, these syllabi endured. They identify a distinctive aspect of Edwarsdean training.

What would Edwards have told Bellamy about preaching? In 1736, Edwards was trying to coax back the revival spirit while transitioning the congregation into a new meetinghouse, so Bellamy would have heard a considerable range of sermon types. Perhaps Edwards shared Cotton Mather's Manuductio ad Ministerium (Boston, 1726), which he himself used, or Solomon Stoddard's Defects of Preachers Reproved (Boston, 1724). Stoddard argued quite vehemently that good preachers were not afraid to preach terror, and they did not rely on notes in the pulpit to do so. For his part, Edwards retained his reliance on a manuscript in the pulpit, even if, by the end of his life, the sermon had shrunk to an outline of only several pages.

Or perhaps Edwards would have impressed on Bellamy his thoughts on preaching as summarized in his preface to the Five Discourses, a collection

27 See Bellamy, "Questions in Theology," appended to Stephen West's 1774 list of questions for theological students, American Antiquarian Society, as cited in Valeri 1994:74, n. 39. 
of sermons from the recent revival that would be published in 1738. There, Edwards observed that sermons with power often appear in "very plain and unpolished dress," and so ministers should "despise such ornaments as politeness, and modishness of style and method, when coming as a messenger from God to souls, deeply impressed with a sense of their danger of God's everlasting wrath, to treat with them about their eternal salvation." "However unable I am to preach or write politely," Edwards continued,

God has showed us he does not need such talents in men to carry on his own work, and that he has been pleased to smile upon and bless a very plain, unfashionable way of preaching. And have we not reason to think that it ever has been, and ever will be, God's manner to bless the foolishness of preaching to save them that believe, let the elegance of language, and excellency of style, be carried to never so great a height, by the learning and wit of the present and future ages?

Edwards' claim to unstudied prose may have been a bit overstated, but his mastery of the plain style was not lost on Bellamy, who became a powerful preacher in his own right.

\subsection{Samuel Hopkins}

Samuel Hopkins is known as the great systematizer and disseminator of Edwards' thought through his many publications. Yet here we are going to focus first on Hopkins as a young seeker, trying to come to some sort of assurance that he was indeed converted. As a Yale student, Hopkins had as his classmates zealous New Lights such as David Brainerd and Samuel Buell. He heard powerful awakening preachers such as George Whitefield and Gilbert Tennent, and, while he experienced raised affections, he could not be sure they had culminated in regeneration. He considered himself "a sinful lost creature." When Hopkins heard Edwards deliver The Distinguishing Marks of a Work of the Spirit of God at Yale's commencement in September 1741 , he found a spiritual as well as an intellectual guide, and resolved to study with him.

But it wasn't study only, or perhaps even primarily, for which he came to Edwards, but for spiritual counseling and guidance. Hopkins, who we might think of as a mild-mannered bookworm and who described himself as "of a sober and steady make," was crippled by uncertainty about the state of his soul. His Diary is a constant revisiting of the question of his salvation, since, in his chosen profession as minister, he would not be qualified if he were not a true saint. Ironically, therefore, we can use Hopkins as an example of another function of the schools of the prophets: spiritual formation. In the context of the Great Awakening, when the New Birth was the great byword, and an 
unconverted ministry the great danger, Hopkins' concerns typified a whole cadre of would-be shepherds of souls.

Interestingly, it was first through the ministrations of Sarah Pierpont Edwards that Hopkins began to have some hope, a circumstance that highlights how the student would also be molded by exposure to his teacher's familial and congregational culture. After living as a recluse for several months following graduation, he came to Northampton; finding Edwards gone on a preaching tour, he spent days alone in his room, gloomy and listless. She noticed this, and drew him out of his shell. For the first time he gave vent to his feelings - "I was in a Christless, graceless state," he confided to her - but she encouraged him, saying that the family expected great things from him. Also, he would have witnessed some or all of her ecstatic and prolonged religious experiences in January 1742. After his return from a preaching tour with Buell, Hopkins was also able to open up to Edwards himself, who asked his pupil why he had not told him these things before, and, as Hopkins recalled, "entertained a hope that I was a Christian" (West 1805:41-43). From that point, Hopkins considered himself as fit to be a minister. After spending another period of study with Edwards in the summer of 1742, and again briefly as Northampton schoolmaster in June 1743 , he embarked on a long career as a minister and theologian.

Publication was another important component of New Divinity education and polemics, and Hopkins provides an entrée into the education and dissemination of the Edwardsean Way through print culture in treatises, tracts, journals and newspapers. If we look only at the posthumous publications of Edwards as an example, Hopkins himself oversaw the printing of some of Edwards' writings, including Two Dissertations and a biography that included a number of previously unpublished sermons (1765). He also helped to create networks, for example, introducing Jonathan Edwards Jr. to John Erksine. Out of this partnership, with Edwards Jr. sending transcripts of his fathers work to Scotland, came A History of the Work of Redemption, collections of sermons and two volumes of selections from Edwards Sr.'s notebooks. ${ }^{28}$

Out of the networks created among New Divinity leaders such as Hopkins came several important reform movements, including the abolition of slavery. Hopkins published a Dialogue (1776) against slavery, and helped to organize other Edwardseans to contribute sermons and newspaper articles to the cause, including Ebenezer Baldwin, Levi Hart, and particularly Edwards Jr., who late in his life made anti-slavery a topic for graduating students' disquisitions at

28 Edinburgh imprints include History of the Work of Redemption (1774), Practical Sermons Never Before Published (1788), Twenty Sermons on Various Subjects (1789), Miscellaneous Observations on Important Theological Subjects (1793), and Remarks on Important Theological Controversies (1796). 
Union College. Together, this group became the earliest organized party for immediate abolitionism in American history. Their influence extended into African Calvinist circles. Hopkins's works were formative for African-American preacher Lemuel Haynes (Conforti 1981:125-58, Minkema \& Stout 2005, Saillant 2003.)

At his church in Newport, Hopkins also encouraged female lay teachers. Sarah Osborn and Susanna Anthony, two members of his congregation, held theological and prayer groups for women, and preached to blacks, building up a small community of free and enslaved black Edwardseans in town. A collection of their correspondence was printed in 1807, and Hopkins published a memoir of Anthony after her death. ${ }^{29}$ Osborn and Anthony attest to the continuing importance of female educators, missionaries, reformers, and writers in Edwardsean circles (Porterfield 1980, McCoy 1995, Kim 2003.)

\section{INSTITUTIONALIZED NEW DIVINITY EDUCATION}

We have seen how Jonathan Edwards, using educational models learned in his home and in college, developed a "familiar" method that involved guiding students through lists of questions in a dialogic manner, imparting practical knowledge about the preacher's role, utilizing visual and textual aids, and recommending books and study methods such as keeping notebooks. Over the succeeding generations, New Divinity pastors continued to run parsonage schools, in which students, with access to the minister's library, were coached in doctrinal knowledge, preaching, and, through immersion in their host's family, in the domestic sphere of the minister. Respected preachers and teachers like John Smalley and Nathanael Emmons took scores of recently minted college graduates and continued their training, turning them into agents of the New Divinity. Meanwhile, other adherents of Edwards, such as Edwards Jr. at Union College in New York, or Timothy Dwight at Yale College, Edward Dorr Griffin at Williams College, Samuel Austin at the University of Vermont, and, later, Moses Stuart and Edwards Amasa Park at Andover Seminary and Nathaniel William Taylor at Yale, became faculty members and leaders of venerable educational centers. Thus, from its beginnings in informal and sporadic apprenticeships, to the parsonage seminary, and finally achieving a presence in public and private colleges and universities, the New Divinity became institutionalized and mainstreamed.

Through the late eighteenth and into the nineteenth centuries, adherents of the New Divinity tradition also established new institutions specifically for

29 Familiar letters, written by Mrs. Sarah Osborn, and Miss Susanna Anthony (Newport, 1807); Hopkins, The life and character of Miss Susanna Anthony (Worcester, 1796). 
the inculcating of Edwardsean principles and priorities such as revivalism and missions. Scholars such as Joseph Conforti, Amanda Porterfield, David Kling, and Charlie Philips have shown the centrality of New Divinity men and women such as Mary Lyons at Mt. Holyoke Seminary for Women, Samuel Mills at Williams College, and Edwards Amasa Park at Andover Seminary (Conforti 1995:87-107, Porterfield 1997, Kling 1996, Philips 2005). We can also point to other institutions, such as Amherst College, Dartmouth College, Andover Seminary, East Windsor Seminary, and Hartford Seminary for Women, as having significant New Divinity origins, influences, and connections. Not coincidentally, these institutions either started as, or came to be taken over by, New Divinity figures, especially in the rural areas of New England, where they dominated the pulpits for several generations (Kling 1993). With the rise of these institutions came new waves of revivals in the early nineteenth century, and the coalescence of missionary movements to domestic and foreign fields, emanating from deep within Edwardsean and neo-Edwardsean circles.

\section{BIBLIOGRAPHY}

ANDERSON, W.A. (ED.) 1980. The Works of Jonathan Edwards, Volume 6, Scientific and Philosophical Writings. New Haven: Yale University Press.

Bailey, R.A. \& Gregory A. W. (EDs.) 2002. The Salvation of Souls: Nine Previously Unpublished Sermons on the Call of Ministry and the Gospel by Jonathan Edwards. Wheaton, III., Crossway.

Chamberlain, A. (ed.) 2000. The Works of Jonathan Edwards, Volume 18, The "Miscellanies," 501-832. New Haven: Yale University Press.

CONFORTI, J. A.

1997. Jonathan Edwards, Religious Tradition, and American Culture. Chapel Hill, University of North Carolina.

1981. Samuel Hopkins and the New Divinity Movement. Grand Rapids: Eerdmans.

DAVIES, R.E.

2006. Missionary benefactor and strange bedfellow: Isaac Hollis, Jonathan Edwards' English correspondent. Baptist Quarterly 41(5):263-280.

Delattre, R. A.

1968. Beauty and Sensibility in the Thought of Jonathan Edwards: An Essay in Aesthetics and Theological Ethics. New Haven: Yale University Press.

EDWARDS, J. JR.

1788. Observations on the language of the Muhhekaneew Indians; in which the extent of that language in North-America is shewn; its genius is grammatically 
traced; some of its peculiarities, and some instances of analogy between that and the Hebrew are pointed out. New Haven.

ENDY, M.B. JR.

1984. Theology and Learning in Early America. In: P. Henry (ed.) Schools of Thought in the Christian Tradition, (Philadelphia, Fortress Press), pp. 125-151.

GAMBreLL, M.

1937. Ministerial Training in Eighteenth-Century New England. New York, Columbia University Press.

George S.C. (ED.)

1998. The Works of Jonathan Edwards, Volume 16, Letters and Personal Writings. New Haven: Yale University Press.

Goen, C.C., (ED.)

1972. The Works of Jonathan Edwards, Volume 4, The Great Awakening. New Haven: Yale University Press.

HAYES, K.

1996. A Colonial Woman's Bookshelf. Knoxville: University of Tennessee Press.

HOPKINS, S.

1765. Life and Character of the Late Rev. Mr. Jonathan Edwards. Boston.

KIM, S.

2003. "Beyond the Men in Black: Jonathan Edwards and Nineteenth-Century Women's Fiction." In: D.W. Kling \& D.A. Sweeney (eds.) Jonathan Edwards at Home and Abroad: Historical Memories, Cultural Movements, Global Horizons. Columbia: (University of South Carolina Press), pp. 137-53.

KIMNACH, W.H.

2006. The Works of Jonathan Edwards, Volume 25, Sermons and Discourses, 1743-1758. New Haven: Yale University Press.

KLING, D.W.

1993. A Field of Divine Wonders: The New Divinity and Village Revivals in Northwestern Connecticut, 1792-1822. University Park, Penn State University Press.

1996. "The New Divinity and Williams College, 1793-1836." Religion and American Culture 6:195-223.

LESSER, M.X.

2001. The Works of Jonathan Edwards, Volume 19, Sermons and Discourses, 1734-1738. New Haven: Yale University Press.

Marsden, G.M.

2003. Jonathan Edwards: A Life. New Haven: Yale University Press.

MATHER, S.

1705. Figures or Types of the Old Testament. $2^{\text {nd }}$ ed., London. 
MccoY, G.

1995. The Women of the ABCFM Oregon Mission and the Conflicted Language of Calvinism. Church History 64 (March): 62-82.

MinKEMA, K. P.

1992. "Sisterhood, Courtship, and Marriage in the Edwards Family in the Early Eighteenth Century," New England Historic and Genealogical Register CXLVI (January).

MinKEMA, K. P. (ED.)

1997. The Works of Jonathan Edwards, Volume 14, Sermons and Discourses, 1723-1729. New Haven: Yale University Press.

MinKeMA, K.P. \& STOUT, H.S.

2005. The Edwardsean Tradition and the Antislavery Debate, 1740-1865. Journal of American History 92 (June).

MITCHELL, L.J.

2003. Jonathan Edwards on the Experience of Beauty. Studies in Reformed Theology and History 9: 1-115.

MOONEY, J. (ED.)

2001. Eighteenth-Century Catalogues of the Yale College Library. New Haven: Yale University.

MORRIS, W.S.

2005. The Young Jonathan Edwards. Eugene, Oregon: Wipf \& Stock.

NICHOLS, W. (ED.)

2001. Seeking God: Jonathan Edwards' Evangelism Contrasted with Modern Methodologies. Ames, lowa, International Outreach.

PARK, E. A.

1876. Jonathan Edwards' Last Will, and the Inventory of His Estate. Bibliotheca Sacra 33 (July).

PauW, A.P. 2003. The Supreme Harmony of All: The Trinitarian Theology of Jonathan Edwards. Grand Rapids: Eerdmans.

PHILIPS, C.

2005. The Last Edwardsean: Edwards Amasa Park and the Rhetoric of Improved Calvinism. Unpublished PhD dissertation, University of Stirling.

Porterfield, A.

1980. Feminine Spirituality in America: From Sarah Edwards to Martha Graham. Philadelphia: Temple University Press.

1997. Mary Lyon and the Mt. Holyoke Missionaries New York, Oxford University Press. 
Ramsey, P. (ED.)

1957. The Works of Jonathan Edwards, Volume 1, Freedom of the Will. New Haven: Yale University Press.

SallinN, J.

2003. Black Puritan, Black Republican: The Life and Thought of Lemuel Haynes, 1753-1833. New York: Oxford University Press.

SARGEANT, J.

1882. A Valedictorian Oration by John Sargeant, Delivered at Yale College in the Year 1729. New York.

Stelting, D.E.

1998. Edwards as Educator: His Legacy of Educational Thought and Practice. Unpublished PhD dissertation, University Of Kansas.

StOUGHTON, J.

1883, Windsor Farmes, 1694-1750: A Glimpse of an Old Parish, Hartford.

Stout, H.S. \&. HATCh, N.O (eds.)

2003. The Works of Jonathan Edwards, Volume 22, Sermons and Discourses, 1739-1742 (New Haven: Yale University Press.

Thuesen, P.J. (Ed.)

2008. The Works of Jonathan Edwards, Volume 26. New Haven: Yale University Press.

TRACY, P.J.

1980. Jonathan Edwards, Pastor: Religion and Society in Eighteenth-Century Northampton. New York: Hill \& Wang.

VALERI, M. 1994. Law and Providence in Joseph Bellamy's New England: The Origins of the New Divinity in Revolutionary America. New York, Oxford University Press.

WARCH, R.

1973. School of Prophets: Yale College, 1701-1733. New Haven: Yale University Press.

WEST, S.

1805. Sketches of the Life of the Late Rev. Samuel Hopkins, D.D. Hartford.

WinsLOW, O.

1941. Jonathan Edwards, 1703-1758: A Biography. New York, MacMillan.

Keywords

Edwards, Jonathan (1703-1758)

Education
Trefwoorde

Edwards, Jonathan (1703-1758)

Opvoeding 
Acta Theologica

2011:2

Bellamy, Joseph

Bellamy, Joseph

Hopkins, Samuel

Hopkins, Samuel 